\title{
Katalogizacija u publikaciji (CIP) u Narodnoj biblioteci Srbije (1986-2021) Cataloguing in Publication (CIP) in The National Library of Serbia (1986-2021)
}

\author{
Nataša Simić \\ Narodna biblioteka Srbije, Beograd, Srbija / National Library of Serbia, Belgrade, Serbia \\ natasa.simic@nb.rs
}

\section{Informacije o članku / Article Info}

Primljen / Received 18. 6. 2021.

Prihvaćen / Accepted 18. 8. 2021.

Dostupan online / Available online: 1. 12. 2021.

\section{Ključne reči / Keywords}

katalogizacija u publikaciji, CIP služba, Narodna biblioteka Srbije

cataloguing in publication, CIP service, National Library of Serbia

\begin{abstract}
Sažetak / Abstract
Ovim radom želim da ukažem na dobru saradnju izdavača i Narodne biblioteke Srbije koja traje punih trideset pet godina. Katalogizacija u publikaciji je zahvaljujući visokostručnom kadru biblioteke stekla ogromno poverenje kod izdavača što se vidi po sve većem broju obrađenih publikacija bez obzira na jezik i pismo.

With this paper, I want to point out the good cooperation between the publisher and the National Library of Serbia, which has lasted for a full thirty-five years. Thanks to the highly professional staff of the library, cataloging in publication has gained great trust among publishers, which can be seen by the growing number of processed publications, regardless of language and script.
\end{abstract}

Katalogizacija u publikaciji omogućava informisanje o knjigama izdavača jedne zemlje čije je izlaženje u toku, čime se ostvaruje praćenje izdavačke produkcije u toj zemlji. Publikacija se katalogizuje jednom, i to u zemlji iz koje potiče izdavač, bez obzira gde će se knjiga štampati. Knjige kojima je urađena katalogizacija mogu se distribuirati i prodavati svuda u svetu zahvaljujući Univerzalnoj bibliografskoj kontroli, uz čiju pomoć se taj obiman posao kataloške obrade knjige obavlja samo jednom.

Katalogizacija predstavlja rešenje jednog od najvećih problema u bibliotekarstvu sa kojim su se suočavali bibliotekari širom sveta. Pronalaženje jedinstvenog rešenja koje bi svima bilo od koristi trajalo je dugo. Prvi pokušaji potiču od bibliotekara Rusije, Engleske i Sjedinjenih Američkih Država. Predlozi koje su oni davali i projekti koje su započinjali, sa manje ili više uspeha, svodili su se na izradu kataloških listića koji bi se distribuirali zajedno sa publikacijom (Тасић 2000, 125).

Najveći problem katalogizacije bio je nedostatak kako međunarodnih tako i nacionalnih standarda u bibliotekarstvu i izdavačkoj delatnosti. Stoga je u Kopenhagenu 1969. godine na sastanku Odbora za katalogizaciju koji je organizovala IFLA ustanovljen međunarodni standardni bibliografski opis monografskih publikacija - ISBD(M) standard. Osnovne karakteristike ovog standarda su: precizno utvrđeni redosled podataka, primena specifičnog interpunkcijskog sistema koji dobija značenje simbola i preuzimanje podataka iz utvrđenih izvora (Симић 2020, 60). Ovaj standard omogućava komunikaciju i razmenu bibliografskih informacija u nacionalnim
Cataloguing in Publication enables information about the books of a one's country publisher for forthcoming publishing, resulting in tracking of publishing production of the concerned country. The publication is catalogued once in the country of origin of the publisher, regardless of where the book is going to be printed. Catalogued books can be distributed and sold anywhere in the world thanks to the Universal Bibliographic Control, by which help, this extensive work of book catalogue processing is done only once.

Cataloguing is a solution to one of the biggest problems in librarianship that librarians around the world have faced. Finding a unique solution that would benefit everyone took a long time. The first attempts came from librarians from Russia, England and the United States of America. The proposals they gave and the projects they started, with more or less success, came down to making catalogue cards, that would be distributed together with the publication. (Tasić 2000, 125).

The biggest problem with cataloguing was the lack of both international and national standards in librarianship and publishing activity. Therefore, in Copenhagen in 1969, at the meeting of the Cataloguing Committee organized by IFLA, the International Standard Bibliographic Description for Monographic Publications - the ISBD (M) standard - was established. The basic characteristics of this standard are: precisely determined order of statements, application of a specific punctuation system that acquires the meaning of symbols and retrieval of data from identified sources (Simić 2020, 60). 
i međunarodnim okvirima u cilju ostvarivanja jedinstvenog bibliotečko-informacionog sistema. Na ovaj način omogućena je razmena zapisa i učinjen veliki korak u savladavanju jezičkih barijera.

Prateći tokove bibliotečke delatnosti u svetu Narodna biblioteka Srbija je 1976. godine, kao članica Zajednice nacionalnih biblioteka SFRJ, potpisala sporazum o primeni međunarodnih standarda za bibliografski opis, o centralizovanoj katalogizaciji na celoj svojoj teritoriji i o međusobnoj razmeni kataloških listića u SFRJ (Савић и Стошић 2001, 132). Primena ovog sporazuma počinje dve godine kasnije kada se Narodna biblioteka uključuje u sistem Univerzalne bibliografske kontrole.

U Republici Srbiji, katalogizacija u publikaciji CIP (Cataloging in publication) počinje 1986. godine kao zajednički projekat izdavača i Narodne biblioteke Srbije. Ovaj projekat je poveren Narodnoj biblioteci kao nacionalnoj instituciji, u kojoj se zahvaljujući visokostručnom kadru različitih profila sa uspehom već trideset i pet godina obavlja ovaj obiman i odgovoran zadatak.

Na samom početku ovog projekta, prijem materijala se vršio u kancelariji gde su dežurali bibliotekari iz Odeljenja autorskog kataloga i Odeljenja predmetnog i stručnog kataloga. Obrada publikacije se vršila na samom prijemu, tako što je svakog dana bilo određeno dežurstvo po jednog bibliotekara Predmetnog i Autorskog kataloga koji tog dana rade katalogizaciju, svako iz svog domena. Izdavači su materijal donosili kao štampane tabake.

Realizacija projekta je u početku išla sporo i veoma često je dolazilo do određenih problema usled nedovoljne informisanosti izdavača o značaju kataloškog zapisa. Preciznost kataloškog zapisa često je dovođena u pitanje zbog nepotpunosti materijala koji je dostavljan na katalogizaciju, nepripremljenosti rukopisa za štampu i naknadnih izmena elemenata koji su ključni za bibliografsku i sadržinsku obradu publikacije (Хаџи-Видановић 2001, 144).

Na samom početku je ovaj projekat bio vezan za projekat Koordinirane nabavke knjiga za biblioteke, tako da je jedan od uslova za otkup bio da svako prvo izdanje mora sadržati CIP zapis. U početnoj fazi projekta (1986-1988) primećen je nedostatak zakonske regulative o izradi zapisa, kao i precizna selekcija građe koja se obrađuje. Zbog toga su 1988. godine komisija za katalogizaciju Saveza društva bibliotečkih radnika Jugoslavije i Zajednica jugoslovenskih nacionalnih biblioteka usvojili određene preporuke za oblik kataloškog opisa publikacije. Unifikacija CIP zapisa se postiže ISBD(M) (International Standard Bibliographical Description for Monographic Publication) standardom iz koga će se kasnije razviti i drugi standardi za obradu različitih vrsta bibliotečkog materijala.
This standard enables communication and exchange of bibliographic information in national and international frameworks in order to achieve unique library information system. In this way, the exchange of records was enabled and a big step was taken in overcoming language barriers.

Following the course of library function in the world, in 1976 the National Library of Serbia, as a member of the Association of National Libraries of Socialist Federal Republic of Yugoslavia, signed an agreement on the application of international standards for bibliographic description, centralized cataloguing throughout its territory and mutual exchange of catalogue card sheets in the Socialist Federal Republic of Yugoslavia (Savić and Stošić 2001, 132). The application of this agreement begins two years later when the National Library is included in the system of Universal Bibliographic Control. In the Republic of Serbia, cataloguing in the publication - CIP began in 1986 as a joint project of the publishers and the National Library of Serbia. This project has been entrusted to the National Library as a national institution, in which, thanks to highly qualified staff of various profiles, this extensive and responsible task has been performed successfully for thirty-five years.

At the very beginning of this project, the accession of materials was done in the office where librarians from the Department of Author Catalogue and the Department of Subject and Systematic Catalogue were on-call duty. The cataloguing of the publication was done at the accession, by every day appointment of on-call duty librarian from Department Author Catalogue and Department of Subject Catalogue, who on that day, catalogue from their own domain. The publishers brought the material as broadsheets.

The realization of the project was slow at the beginning and very often there were certain problems due to insufficient awareness of the publisher about the importance of the catalogue entry. The accuracy of the catalogue entry is often questioned due to the incompleteness of the material submitted for cataloguing, the unpreparedness of the manuscript for printing and subsequent changes in the elements that are crucial for bibliographic and subject cataloguing of the publication (Hadži-Vidanović 2001, 144).

At the very beginning, this project was related to the project Coordinated Book Accession for Libraries, so one of the conditions for the purchase was that each first edition must contain a CIP record. In the initial phase of the project (1986-1988), the lack of legislation on the creation of records was noticed, as well as the precise selection of the catalogued material. Therefore, in 1988, the cataloguing commission of the Association of Librarians of Yugo- 
Pristupanjem Narodne biblioteke u kooperativnu kataloško-bibliografsku bazu podataka (OPACCOBIB) postaju dostupne bibliografske informacije o fondovima biblioteka koje su međusobno povezane. Ovo predstavlja početak druge faze realizacije CIP projekta. Za ostvarivanje ideje o razmeni bibliografskih zapisa na međunarodnom nivou bilo je neophodno stvoriti međunarodni komunikacioni format koji bi koristile sve ustanove koje učestvuju u razmeni. Kao rešenje ovog problema nastaje UNIMARC (Format for Bibliographic Information Interchange on Magnetic Tapa).

Nije postojala zakonska regulativa koja je obavezivala izdavače da svoje publikacije pre štampanja donesu u Narodnu biblioteku Srbije kako bi publikacija dobila kataloški opis - CIP zapis. Prvi pravni akt kojim je regulisano sprovođenje katalogizacije u publikaciji je Zakon o izdavanju publikacija (Службени гласник PC, бр. 37, 1991) i Zakon o bibliotečko-informacionoj delatnosti (Службени гласник РC, бр. 34, 1994).

Donošenjem ovih zakona, katalogizacija postaje zakonski utvrđena obaveza izdavača i Narodne biblioteke Srbije. U cilju što uspešnije realizacije projekta biblioteka je uspostavila saradnju sa Jugoslovenskim bibliografsko-informacijskim institutom (JUBIN) gde su izdavači mogli da nabave međunarodne brojeve za materijal koji predaju na katalogizaciju. Usled sve većeg odziva izdavača, biblioteka određuje jednu prostoriju za prijem materijala, gde je radilo dvoje knjižničara koji su materijal primali i prosleđivali na obradu.

U Narodnoj biblioteci izdavači mogu da se informišu o materijalu za koji se izrađuje ili ne izrađuje CIP zapis. Prema stručnom uputstvu o katalogizaсіji (Службени гласник РС, бр. 86, 2012) CIP zapis se izrađuje za bibliotečko-informacionu građu koja se nalazi u završnoj fazi pripreme za štampu i objavljivanje, a objavljuje se u papirnoj ili elektronskoj formi.

CIP zapis se ne izrađuje za reklamne prospekte, interna dokumenta, roto-romane, uputstva za rukovanje i održavanje, pozivnice, zidne i druge kalendare koji nemaju edukativan karakter. Katalogizacija u publikaciji kao zajednička obaveza izdavača i Narodne biblioteke Srbije je prema vrsti publikacije koja se obrađuje podeljena na:

- monografske publikacije u jednoj ili više svezaka čije je izdavanje zaključeno,

- serijske publikacije (časopisi, zbornici, godišnjaci....) i

- neknjižna građa (fonodokumenta, audiovizuelna građa, atlasi, štampane muzikalije, geografske karte). slavia and the Association of Yugoslav National Libraries adopted certain recommendations for the form of cataloguing description of the publication. Unification of CIP records is achieved by ISBD (M) (International Standard Bibliographic Description for Monographic Publication) standard from which later other standards for different types of library material cataloguing will be developed.

Bibliographic information on library funds that are interconnected become available by the National Library's joining in the cooperative catalogue-bibliographic database (OPACCOBIB). This is the beginning of the second phase of the CIP project. In order to realize the idea of exchanging bibliographic records at the international level, it was necessary to create an international communication format that would be used by all institutions participating in the exchange. UNIMARC (Format for Bibliographic Information Interchange on Magnetic Tape) is arising as a solution to this problem.

There was no legislation that obliged publishers to bring their publications to the National Library of Serbia before printing in order for the publication to receive a cataloguing description - CIP record. The first legal act that regulates the implementation of cataloguing in publication is the Law on Publishing (Službeni glasnik RS, no. 37, 1991) and Law on Library and Information Activities (Službeni glasnik $R S$, no. 34, 1994).

The adoption of these laws, the cataloguing project becomes a legally established obligation of the publisher and the National Library of Serbia. In order to realize the project as successfully as possible, the library has established cooperation with the Yugoslav Bibliographic and Information Institute (JUBIN) where publishers could obtain international numbers for the material they submitted for cataloguing. Due to the growing response of publishers, the library designates one room for materials accession, where two librarians worked, received and forwarded the material for cataloguing.

In the National Library, publishers can find out about the material for which a CIP record is being created or not. According to the instruction guide on cataloguing (Službeni glasnik RS, no. 86, 2012) According to the instruction guide on cataloguing (Službeni glasnik RS, no. 86, 2012), the CIP record is made for library and information material that is in the final phase of preparation for printing and publishing, and is published in paper or electronic form.

CIP record is not created for brochures, internal documents, pop novels, operating and maintenance instructions, invitations, wall and other non-educational calendars. Cataloguing in publication as a joint obligation of the publisher and the National Library of Serbia is divided into: 

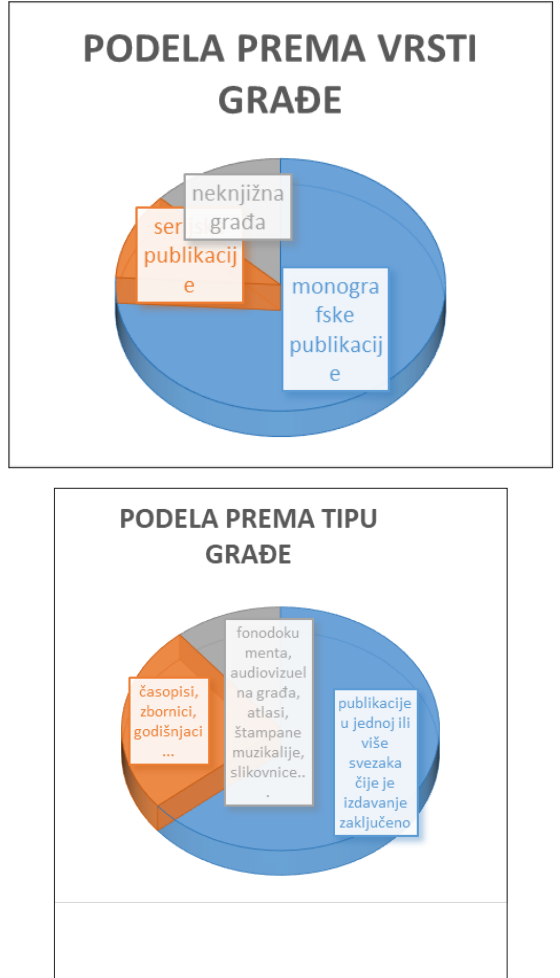

Grafički prikaz podele materijala za obradu po vrsti i tipu

Nakon rekonstrukcije Narodne biblioteke i ukidanja ustanova nekadašnje savezne države dolazi 2003. godine do prebacivanja svih međunarodnih agencija u Narodnu biblioteku. Nekako u isto vreme dolazi do formiranja CIP-službe u okviru Odeljenja monografskih publikacija, čiji je zadatak bio prijem i trijaža materijala za katalogizaciju. Služba za prijem i trijažu materijala imala je svoj poseban ulaz, tako da izdavači više nisu morali da ulaze u biblioteku kako bi predali materijal za CIP. (Симић 2020, 66)

Formiranjem CIP-službe došlo je do objedinjenog prijema materijala za sva odeljenja obrade. Prilikom prijema dolazi do razvrstavanja građe po odeljenjima, po unapred utvrđenim pravilima koje odeljenje obrađuje koju vrstu građe. Ova služba je takođe vršila prijem zahteva za određene Međunarodne brojeve (ISSN i ISMN), kao i prijem materijala za obradu sastavnih delova publikacije.

Zbog porasta broja izdavača i njihove produkcije, a i zbog sve veće primene internetskog poslovanja, CIP služba Narodne biblioteke Srbije je, početkom 2020. godine, počela materijal za katalogizaciju da prima putem imejla. Izdavačima je data mogućnost da materijal pošalju na jasno naznačen i u te svrhe otvoren imejl. Materijal koji se šalje elektronskim putem mora da sadrži sve potrebne podatke za katalogizaciju.

Osnovni zadatak CIP-a je da daje brzu informaciju o novim naslovima. Njegove funkcije su višestruke: služi kao najava knjige, pospešuje prodaju, pospešuje marketing i edukuje nove izdavače. Zadatak
- monographic publications in one or more volumes whose publication has been concluded,

- serial publications (journals, proceedings, yearbooks...) and

- nonbook materials (phono documents, audio-visual materials, atlases, sheet music, geographical maps).
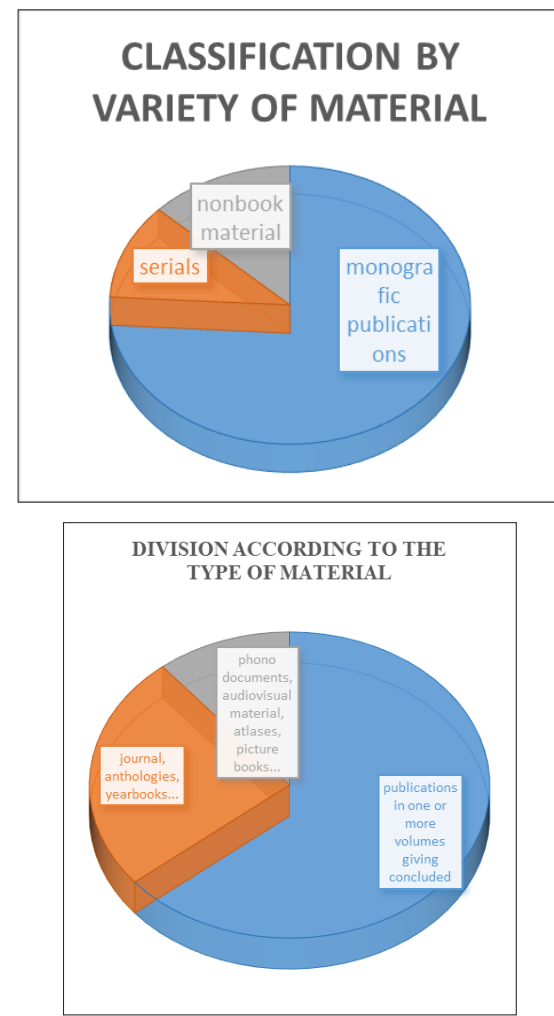

Graphic representation of the classification of processing materials by variety and type

After the reconstruction of the National Library and the abolition of the institutions of the former Federal state, in 2003 all international agencies were transferred to the National Library. Somehow, at the same time, the CIP service was formed within the Department of Monographic Publications, whose task was to receive and triage cataloguing materials. The Accession and triage of materials service had its own separate entrance, so publishers no longer had to enter the library to submit materials for the CIP. (Simić 2020, 66)

With the formation of the CIP service, there was a unified accession of materials for all processing departments. Upon accession, the material is sorted by departments, according to pre-established rules that which department processes which type of material. This service also received requests for certain international numbers (ISSN and ISMN), as well as accession of materials for processing the component parts of the publication.

Due to the increase in the number of publishers and their production, and also due to the increasing use 
katalogizacije je da obezbedi informaciju o novim knjigama i da prati izdavačku produkciju jedne zemlje. Katalogizacija u publikaciji služi i kao najava knjiga. Izdavačima omogućava izradu sopstvenih kataloga izdatih knjiga i omogućava uvid u nacionalnu izdavačku produkciju. Služi za međunarodnu promociju knjige. Izdavači u sve većem broju shvataju značaj katalogizacije. Katalogizacija u publikaciji ima ogroman nacionalni značaj, jer je to pravi izvor informacija o izdavačkoj produkciji jedne zemlje. Najveći značaj katalogizacija ima za autore, pošto im je zbog kontinuiranog rada službe za katalogizaciju u Narodnoj biblioteci omogućen uvid u sve što je izdato u poslednjih trideset i pet godina. $U$ sledećem grafikonu je prikazan porast broja zapisa, sa presekom na pet godina. Kako ova godina (2021) još uvek nije završena, podaci za tu godinu su do 31. 5. 2021. godine.

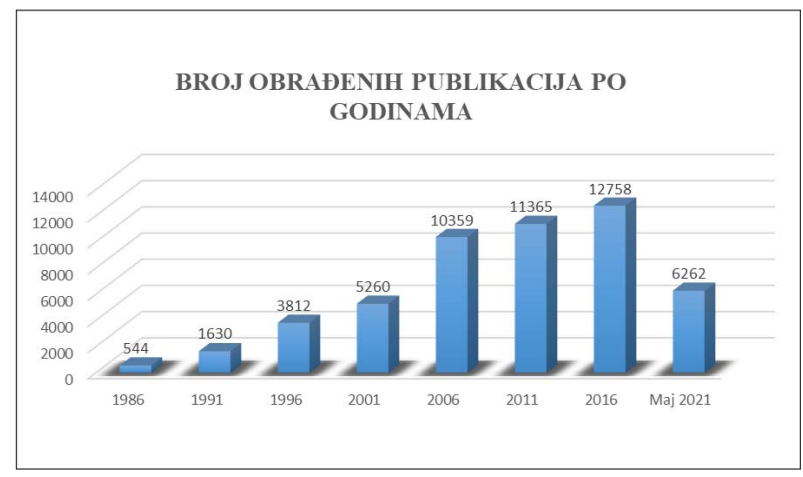

Grafički prikaz broja CIP zapisa po godinama

Zahvaljujući visokostručnom kadru različitog profila koji primenjuje savremene kataloško-bibliografske principe na nacionalnom i međunarodnom nivou, izrada kataloškog zapisa se već punih trideset godina uspešno obavlja u Narodnoj biblioteci Srbije. Veliki broj knjiga koje svakim danom stižu na katalogizaciju dokaz je poverenja koje su za ovih trideset i pet godina izdavači stekli u jednu od najznačajnijih nacionalnih ustanova. Katalogizacija u Narodnoj biblioteci obavlja se bez obzira na jezik i pismo. Upravo to je ono što elektronski katalog biblioteke čini multinacionalnim i multietničkim. of internet business, the CIP service of the National Library of Serbia, at the beginning of 2020, started to receive cataloguing material by e-mail. Publishers are given the opportunity to send the material to a clearly designated and for that purpose opened email. Material sent electronically must contain all the necessary data for cataloguing.

The main task of the CIP is to provide quick information about new titles. Its functions are multiple: serves as a book announcement, boosts sales, boosts marketing and educates new publishers. The task of cataloguing is to provide information about new books and to follow the publishing production of a country. Cataloguing in publication also serves as an announcement of books. It enables publishers to create their own catalogues of published books and provides insight into national publishing production. It is used for international book promotion. Publishers are increasingly realizing the importance of cataloguing. Cataloguing in publication has a grand national significance, because it is a real source of information about the publishing production of a country. Cataloguing is of the greatest importance for authors, because due to the continuous work of the cataloguing service in the National Library, they have been provided with an insight into everything that has been published in the last thirty-five years. The following chart shows the increase in the number of records, with a cross-section of five years. As this year (2021) still has not ended, the data for that year is until the 31st May 2021.

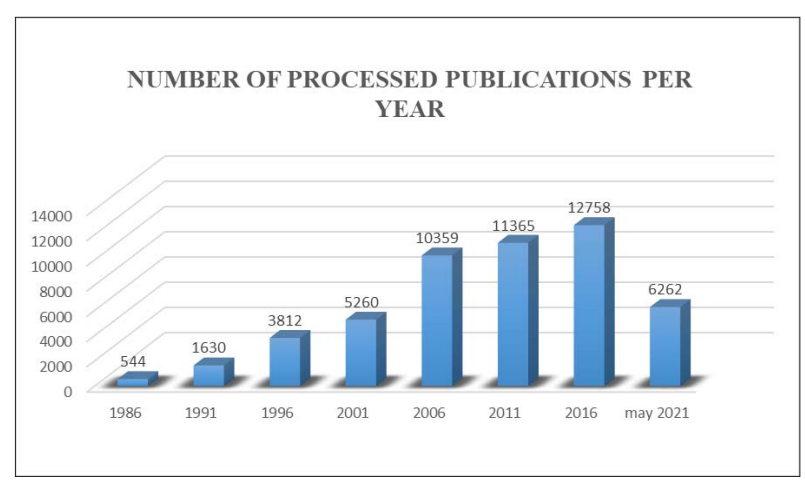

Graphic display of the number of CIP records per year

Thanks to highly professional staff of various profiles who apply modern cataloguing and bibliographic principles at the national and international level, creation of catalogue records has been successfully performed in the National Library of Serbia for thirty years. The large number of books that arrive for cataloguing every day is proof of the trust that publishers have gained in one of the most important national institutions in these thirty-five years. Cataloguing in the National Library is performed regardless of the language and script. This is exactly what makes the electronic catalogue of the library multinational and multi-ethnic. 


\section{Literatura}

Бабовић, Мирјана. 1986. “Каталогизација у публикацији (CIP)" У Библиотечки каталози: материјали са саветовања одржаног у Народној библиотеции Србије, Београд, 15. април 1986, 22-25. Београд: НБС.

Бабовић, Мирјана и Светлана Јанчић. 1985. Алфабетски каталог монографских публикација: израда и формирање. Бероград: Народна библиотека Србије.

“Закон о издавању публикације”, Службени гласник РС бр. 37 (1991).

“Закон о библиотечко-информационој делатности”, Службени гласник РС бр. 34 (1994).

Јанчић, Светлана. 1986. “Скраћени каталошки опис монографских публикација” у Библиотечки каталози: материјали са саветовања одржаног у Народној библиотеции Србије, Београд, 15. април 1986, 52-58. Београд : НБС.

Хаџи-Видановић, Јагода. 2001. “Каталогизација у публикацији: заједнички пројекат Народне библиотеке Србије и издавача" Гласник Народне библиотеке Србије 3 (1): 143-157.

Савић, Ана и Славјана Стошић. 2001. “ЦИП - од идеје до пројекта: искуство у Србији и Аустралији" Гласник Народне библиотеке Сpбuje 3 (1): 131-142.

Симић, Наташа. 2020. “Каталогизација у публикацији (CIP) између теорије и праксе, на примеру развоја СIP-службе у Народној библиотеци Србије" Корак библиотеке 5: $59-70$.

Стаматовић, Десанка. 1978. “Каталогизација на извору - значај и могућности примене” Библиотекарство 24 (4): 68-78.

Станковић, Добрила. 1979. Упутство за применy $\operatorname{ISBD}(M)$. Београд: Народна библиотека Србије.

“Стручно упутство за каталогизацију у публикацији (СІР)", Службени гласник РС бр. 86 (2012).

Тасић, Тања. 2000. “Каталогизација у публикацији (ЦИП) у Народној библиотеци Србије" Гласник Народне библиотеке Србије 2 (1): 125-131.

\section{Bibliography}

Babović, Mirjana. 1986. "Katalogizacija u publikaciji (CIP)" U Bibliotečki katalozi: materijali sa savetovanja održanog u Narodnoj biblioteci Srbije, Beograd, 15. april 1986, 22-25. Beograd: NBS.

Babović, Mirjana i Svetlana Jančić. 1985. Alfabetski katalog monografskih publikacija: izrada $i$ formiranje. Berograd: Narodna biblioteka Srbije.

"Zakon o izdavanju publikacije”, Službeni glasnik $R S$ br. 37 (1991).

"Zakon o bibliotečko-informacionoj delatnosti", Službeni glasnik RS br. 34 (1994).

Jančić, Svetlana. 1986. "Skraćeni kataloški opis monografskih publikacija" U Bibliotečki katalozi: materijali sa savetovanja održanog u Narodnoj biblioteci Srbije, Beograd, 15. april 1986, 52-58. Beograd: NBS.

Hadži-Vidanović, Jagoda. 2001. "Katalogizacija u publikaciji: zajednički projekat Narodne biblioteke Srbije i izdavača" Glasnik Narodne biblioteke Srbije 3 (1): 143-157.

Savić, Ana i Slavjana Stošić. 2001. "CIP - od ideje do projekta: iskustvo u Srbiji i Australiji”" Glasnik Narodne biblioteke Srbije 3 (1): 131-142.

Simić, Nataša. 2020. "Katalogizacija u publikaciji (CIP) između teorije i prakse, na primeru razvoja CIP-službe u Narodnoj biblioteci Srbije" Korak biblioteke 5: 59-70.

Stamatović, Desanka. 1978. "Katalogizacija na izvoru - značaj i mogućnosti primane" Bibliotekarstvo 24 (4): 68-78.

Stanković, Dobrila. 1979. Uputstvo za primenu $I S B D(M)$. Beograd: Narodna biblioteka Srbije.

"Stručno uputstvo za katalogizaciju u publikaciji (CIP)", Službeni glasnik RS br. 86 (2012).

Tasić, Tanja. 2000. "Katalogizacija u publikaciji (CIP) u Narodnoj biblioteci Srbije" Glasnik Narodne biblioteke Srbije 2 (1): 125-131. 